\title{
Conditions of development of structural relief in crystalline rocks (case study: Murmansk Upland and Kandalaksha region, Kola Peninsula, Russia)
}

\author{
Józef Superson, Miłosz Huber, Wojciech Zgłobicki \\ Faculty of Earth Sciences and Spatial Management, Maria Curie-Skłodowska University, Lublin, Poland, \\ jozef.superson@poczta.umcs.lublin.pl
}

\begin{abstract}
Structural relief is exceptionally recognisable in areas where igneous and metamorphic rocks without a Quaternary cover occur, which is the case with the Kola Peninsula. However, the subject of structural relief has been addressed relatively rarely. Therefore, an attempt was made to estimate the influence of tectonic and lithologic factors on the relief within two test areas, each covering approximately $100 \mathrm{~km}^{2}$, located on the coast of the Barents Sea (Murmansk Terrane) and the White Sea (Lapland Granulite Belt). The structural relief here is varied, which results from differences in the geological structure. In the former area, depressions and tectonic blocks of varying size and order predominate, while east of Kandalaksha these are flattened hills with asymmetrically inclined slopes (having the character of cuestas). Although lithologically diverse, the test areas share a common feature: the presence of numerous faults and dislocation zones that in the case of the Barents Sea caused the division of igneous rocks into several blocks of various orders. Most of the relief forms in this area were found to have structural origins, namely valley depressions of various orders, slopes and escarpments, lake basins and seaside cliffs. The structural relief of the Murmansk Terrane is determined by disjunctive structures. In the case of the Lapland Granulite Belt, the relief of the analysed macroblock is closely linked with the formation and position of the rocks - this is escarpment relief.
\end{abstract}

Key words: crystalline rocks, structural relief, Kola Peninsula

\section{Introduction}

The Kola Peninsula constitutes the northern part of the Baltic Shield, composed of crystalline rock, highly metamorphosed in some places (Bogatsky et al. 1996). Contemporary studies indicate that the peninsula consists of eight terranes: Murmansk, Kola-Norwegian, Keivy, Sosnovka, Belomorian, Strelna, Tersk and Belomorian Terrane (Fig. 1). They have a different geological structure that influences the diverse structural relief of the particular areas. Despite the very interesting structural relief of the Kola Peninsula and its determinants, researchers are not interested in this problem (Grave 1966). Geomorphological studies are primarily concerned with glacial and fluvioglacial forms (e.g. Hättestrand, Clark 2006) and the development of denudational relief (e.g. Armand et al. 1969, Grave et al. 1991, Mitiaiev, Gierasimova 1994, Pękala 1994, Superson 1994, Goliszek, Pękala 1996, Harasimiuk et al. 1996).

The objective of this study was to compare the style of structural relief of two areas with a different geological structure, and to identify the determinants of the development of this relief. The geomorphological and geological comparative studies were conducted in the selected areas of the Murmansk Terrane and Belomorian Terrane. Within the Murmansk Terrane, the Dalnye Zelentsy area, covering approx. $100 \mathrm{~km}^{2}$, was investigated in detail, while within the Belomorian Terrane, the Kandalaksha region was selected: the area belongs to the south-eastern edge of the Lapland Granulite Belt (Kozlov, Ivanov 1991). Field studies there were conducted within a macroblock covering $105 \mathrm{~km}^{2}$, located east of Kandalaksha. For both test areas geomorphological mapping and basic geological studies and measurements (directions of tectonic fractures) were made.

\section{Geological structure of the Murmansk Terrane and the Lapland Granulite Belt (Belomorian Terrane)}

On the south-west, the Murmansk Terrane is bordered by a thrust on two terranes, Keivy and Kola-Norwegian, while the Murmansk fault running along the shore of the Barents Sea forms the north-eastern border (Fig. 1). These borders, having the status of the main tectonic zones of the Kola Peninsula, have Precambrian or- 


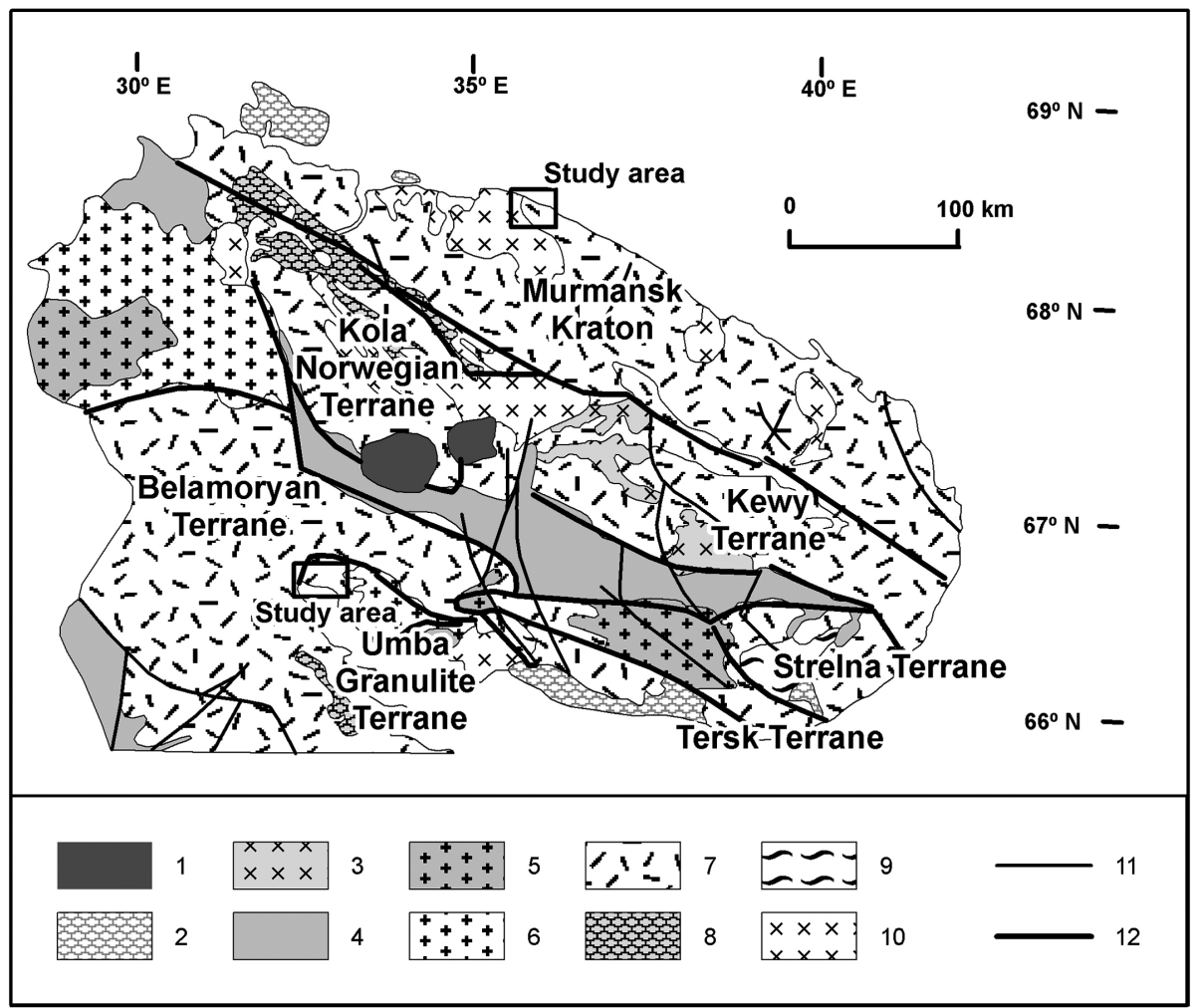

Fig. 1. Location of study areas against the geological structure of the Kola Peninsula (geology acc. to Balagantsky et al. 2012) 1 - Paleozoic alkaline Khibina and Lovozero alkaline; 2 - Neoproterozoic sedimentary rocks complex; 3 - Paleoproterozoic granite, granodiorite and diorite; 4 - Paleoproterozoic volcanic and sedimentary rocks; 5- acid granulite; 6 - basic intermediate granulite; 7 - plagiogranite, granite-gneiss and migmatite; 8 - gneiss and schist; 9 - amphibolite and gneiss; 10 - granodiorite and diorite; 11 - subvertical faults; 12 - thrusts

igins (Bogatsky et al. 1996, Balangansky et al. 2012). In terms of relief, the Murmansk Terrane is a hilly upland mainly composed of Archaean (3.2-2.5 Ga) granites, granodiorites and diorites. Within these rocks, there are palaeozoic intrusions of alkaline rocks, mainly basalts (Mitrofanov 2001). Two dikes also occur in the Dalnye Zelentsy region: between Zelentsy Bay and Shelpino Bay, and south-west of Porchnikha Bay (Mitrofanov 2001, Terekhov et al. 2010).

The Murmansk Terrane is highly fragmented into mega-, macro-, meso- and microblocks by a dense network of faults of different orders. These faults are perpendicular, oblique and parallel to the main Murmansk fault (Fig. 2).

In the Dalnye Zelentsy region, the main fracture occurs there (1) and three narrow zones of the second order, radiating from Jarnishna Bay (Mitiaev, Gierasimova 1994, Zgłobicki 1994). One of them (2) runs parallel to the break, the other two ( 3 and 4) cross the terrane at an oblique angle. These zones are bordered by four macroblocks; the study area encompasses the entire block $\mathrm{A}$ and the north-western parts of the remaining blocks (B, C and D) (Fig. 3).

The macroblocks are dissected by a dense network of faults and joints. In the Dalnye Zelentsy region, a primarily orthogonal joint system occurs (fracturing parallel and perpendicular to the main axis of the craton) while a rhomboidal system (parallel and diagonal fracturing) occurs to a lesser extent. In some areas, a combination of the two systems occurs (Fig. 4). Particularly noteworthy,

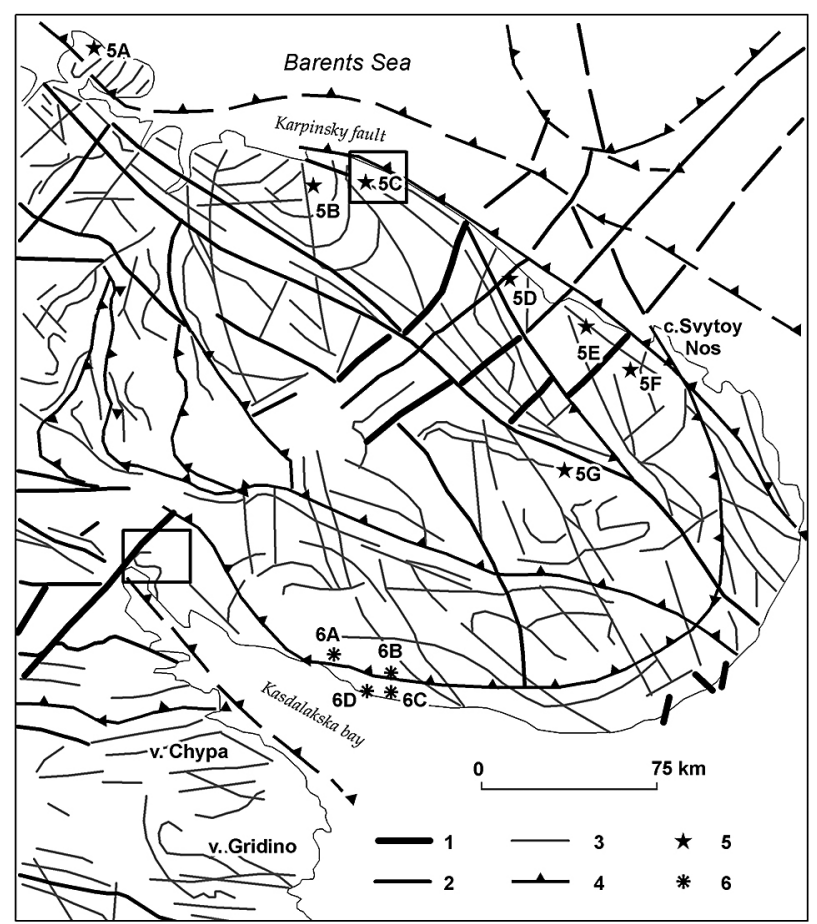

Fig. 2. Tectonic structures and lineaments of the Kola Peninsula (acc. to Terekhov et al. 2010)

1 - structural be conditioned by rifting of the East Barents trough; 2 - structural connect with drifting; 3 - photolineaments, 4 - overtrusts; 5 - basaltic dike areas: $5 \mathrm{~A}$ - Sredny peninsula; $5 \mathrm{~B}$ - Teriberka, 5C - Dalnye Zelentsy, 5D - Drozdovka, 5E - Ivan Guba, 5F - Jokonga; 6 - expliosion pipes at Terskij Breg 


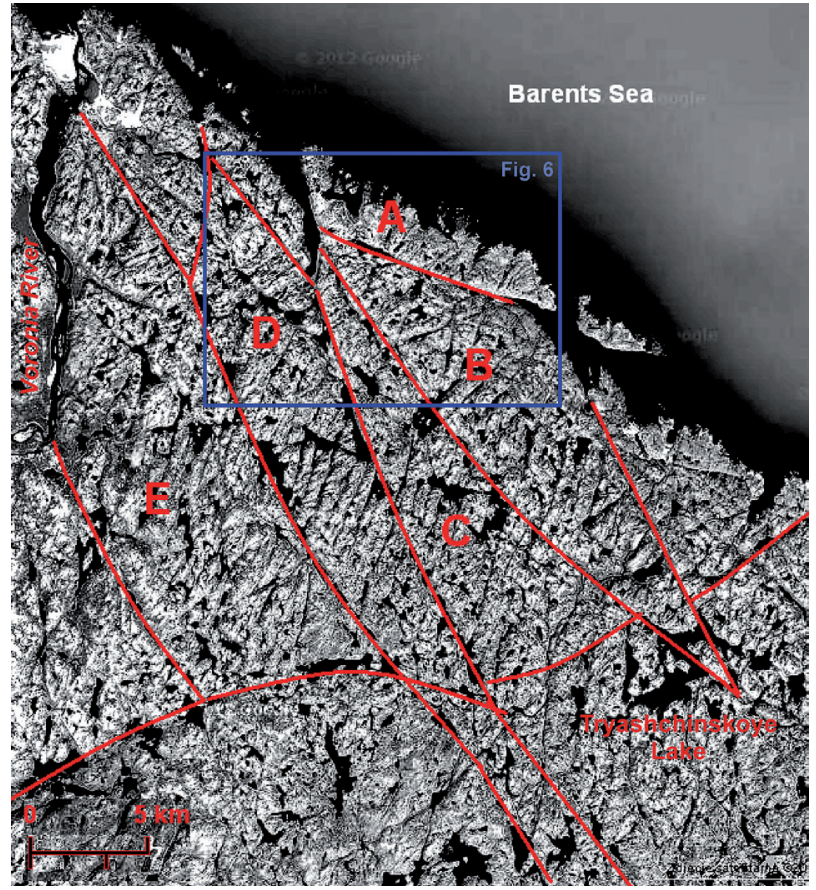

Fig. 3. Tectonic zones and blocks of the Dalnye Zelentsy region (photo based on Google Maps)

Red lines - boundary blocks; A, B, C, D, E - tectonic blocks

is the clear correlation between the direction of the joints and directions of the depressions of various orders.

The Kandalaksha region within the Lapland Granulite Belt lies in the vicinity of late Proterozoic/Palaeozoic rift structures (Bogdanova et al. 1996). The local metamorphism of sedimentary rock and the formation of dike rocks are probably linked to rifting processes. Some dike rocks are younger as they are approx. 350 million years old. The Kandalaksha part of the Lapland Granulite Belt is mainly built of amphibolite rocks originating from sedimentary and volcanic formations (Kozlov et al. 1990).
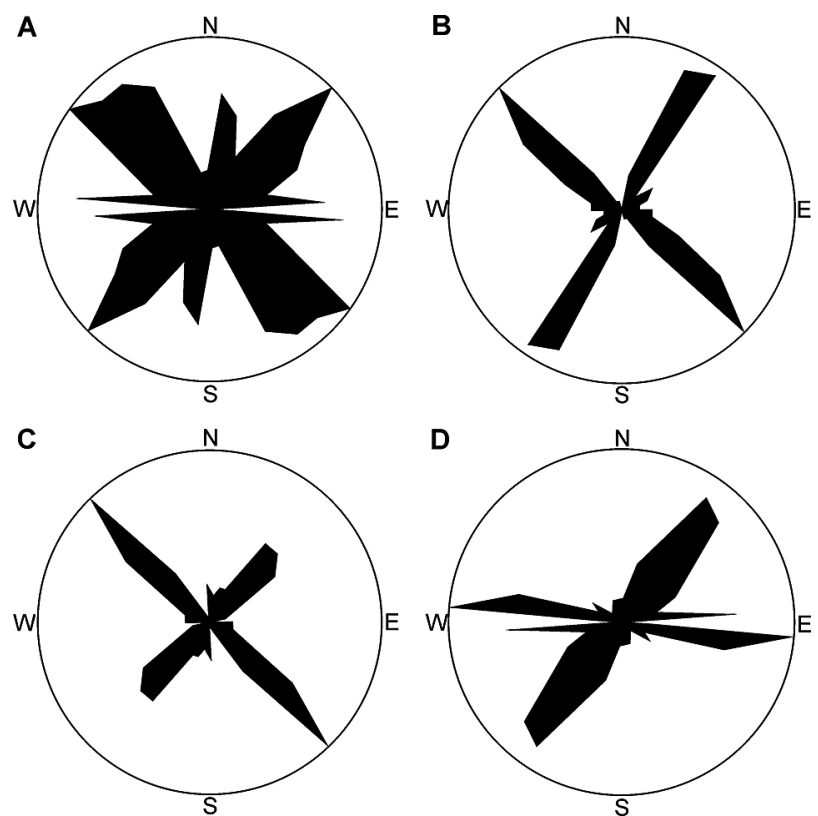

Fig. 4. Directions of joint in the Dalnye Zelentsy region

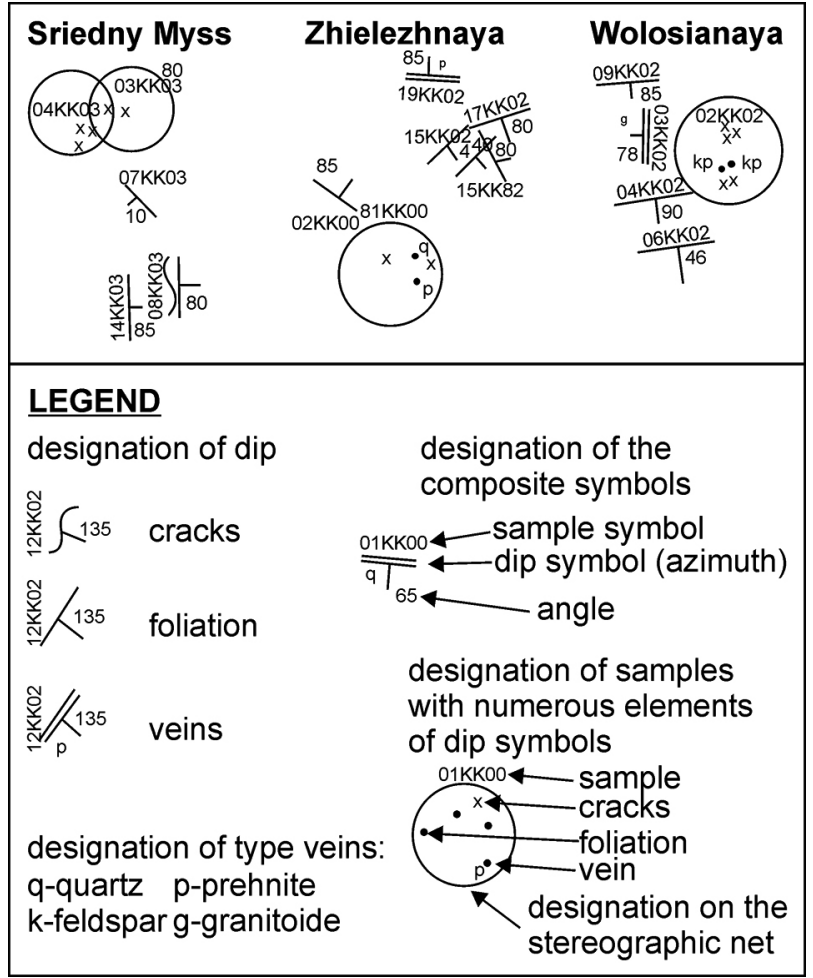

Fig. 5. System of fracturing of rocks in the Kandalaksha region

Granulites also occur among these rocks, particularly within tectonic zones (Kozlova, Riehzienova 1998, Tuisku, Huhma 1998, Bogdanova et al. 1993, 1996). Various dike rocks, cross-cutting the amphibolites and granulites, occur in the south-eastern part of the Lapland Granulite Belt, in the Kandalaksha region. Granitoid and feldspar dikes are N-S, NNW-SSE and WSW-ENE oriented. Quartz dikes also demonstrate an N-S as well as W-E and SSE-NNW orientation. An analysis of the dikes and joints (Fig. 5) indicated that dikes with a different composition often had the same orientation.

The rocks of the Lapland Granulite Belt are densely dissected by faults and flaked folds. The fault system has a flower-like structure. Horsts with a northern vergence are visible throughout the study area. Furthermore, hinge faults are visible particularly on the northern slopes of the Siennaya Kurtiazhnaya and Srednyj Myss mountains. It is an extensive system associated with the transpressional tectonics of the Kola Peninsula (Gaal et al. 1989, Korja 1996, Mitrofanov 1999, Mitrofanov et al. 2000).

\section{Structural relief of the Murmansk and Belamoryan terranes}

The structural relief of the Murmansk Terrane was characterised based on the Dalnye Zelentsy region, while the structural elements of the Belamoryan Terrane were described based on a macroblock in the Kandalaksha region.

The structural relief of the Dalnye Zelentsy region consists of the following elements (Fig. 6): 


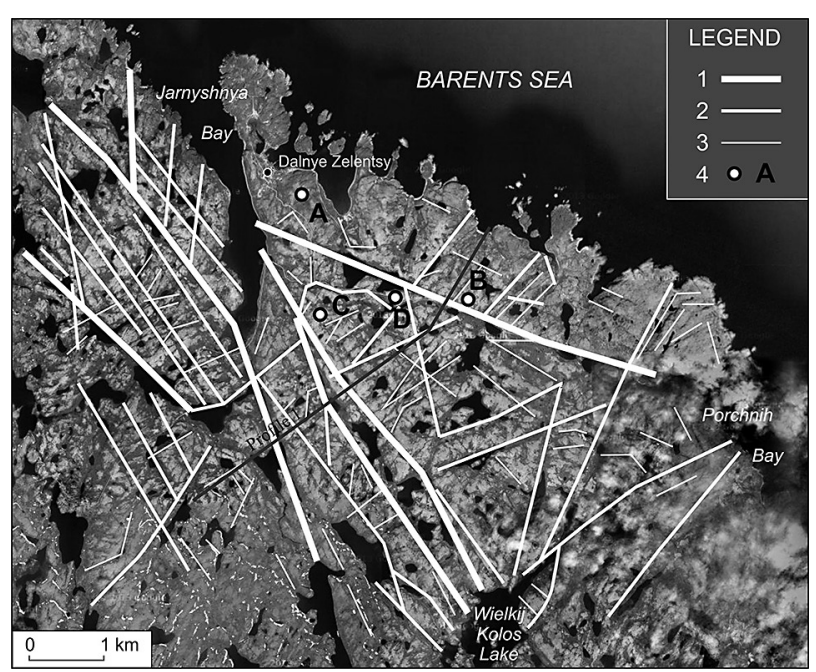

Fig. 6. Photolineaments in the relief of the Dalnye Zelentsy region (photo based on Google Maps)

1 - photolineaments I-rank; 2 - photolineaments II-rank; 3 - photolineaments III-rank; 4 - sites of the joints measurement

- valley depressions that developed on grabens and semi-grabens of various orders,

- tectonic macro-, meso- and microblocks,

- slopes of tectonic origin,

- basins formed on tectonic nodes,

- small valley depressions that developed on faults and fractures,

- small contemporary tension fractures.

The valley depression that formed in the fault zone (2)

is WNW-ESE oriented and extends from Jarnishna Bay to Porchnikha Bay. The north-eastern slope of the depression is steep, straight and clear, while the south-western slope consists of several descending steps (Fig. 7). Furthermore, it is densely dissected by numerous transverse depressions of a lower order. The shape of the depression suggests that it developed on a semi-graben, and the faults are antithetic. The depressions that developed on tectonic zones ( 3 and 4 ) have a similar cross-section: the north-eastern slope is fragmented to a small extent, with one ledge at its foot; the south-western slope is highly fragmented, with three ledges (Fig. 7).

In the Dalnye Zelentsy region, the Murmansk fracture and three main tectonic zones separate four tectonic macroblocks (A, B, C and D). The rhomboidal block A, measuring $12 \times 5 \mathrm{~km}$ and WNW-ESE oriented, is located to the south-west of the Murmansk fault. The block has a dense network of valley depressions formed on perpendicular faults, in some places parallel to the main tectonic zones, and on joints. The depressions divide the block into several meso- and microblocks. The mesoblocks are also rhomboidal, and their longer axis is usually SSW-NNE oriented. The microblocks occur in different shapes, depending on the density and direction of the joints (Fig. 3).

Block B is larger than block A, in the shape of an elongated triangle, its base being $25 \mathrm{~km}$ and its height $6 \mathrm{~km}$. The block extends parallel to the Murmansk break, from Jarnishna Bay in the north-west to the Tryashchinskoye Lake in the south-east. The block is dissected by a dense network of faults of the third order, parallel, perpendicular and oblique to the boundary faults of the second order. The faults divide blocks of different orders. Within the tectonic blocks, valley depressions of various orders and sizes formed on the faults and joints. The bottoms of these depressions are covered by glacial gravel. Basin-like depressions, mostly filled with lakes, are an interesting structural form within this block. They occur at the intersection of the faults that form tectonic nodes. The shape of most depressions and lakes corresponds to the orientation of the faults.

Another tectonic macroblock $(\mathrm{C})$ is in the shape of an elongated triangle whose top is located in Jarnishna Bay, while its base is the transverse tectonic zone in the vicinity of the Tryashchinskoye Lake (Fig. 2). Most of the faults and joints within the block are parallel and oblique to the boundary tectonic zones of the second order. They divide the block into meso- and microblocks of varying shape and varying absolute height.

Macroblock D is a narrow belt extending from the mouth of the Voronia River and Jarnishna Bay to the transverse tectonic zone in the vicinity of the Tryashchinskoye Lake (Fig. 3). Similarly, to block B, it is divided into meso- and microblocks by faults that are parallel, perpendicular and oblique to the boundary tectonic zones.

The meso- and microblocks are delimited by depressions of different orders and escarpments developed on faults and joints. In macroblock A, most of these forms

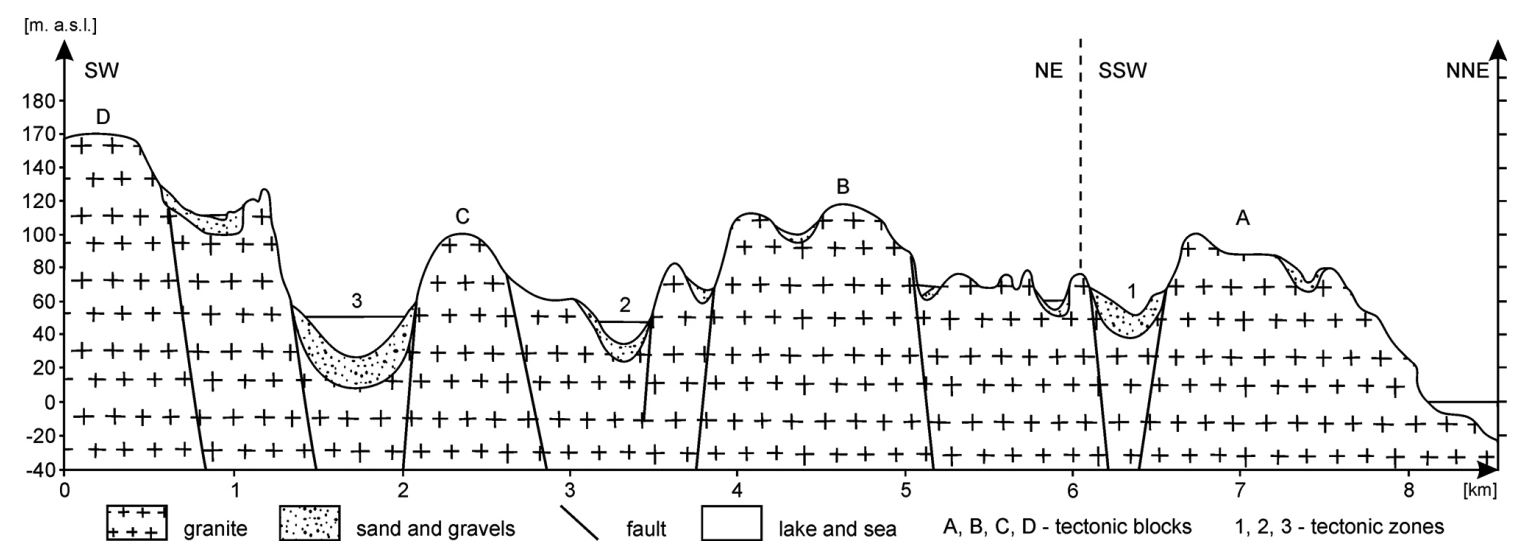

Fig. 7. Morphological section across the macroblocks of the Dalnye Zelentsy region 


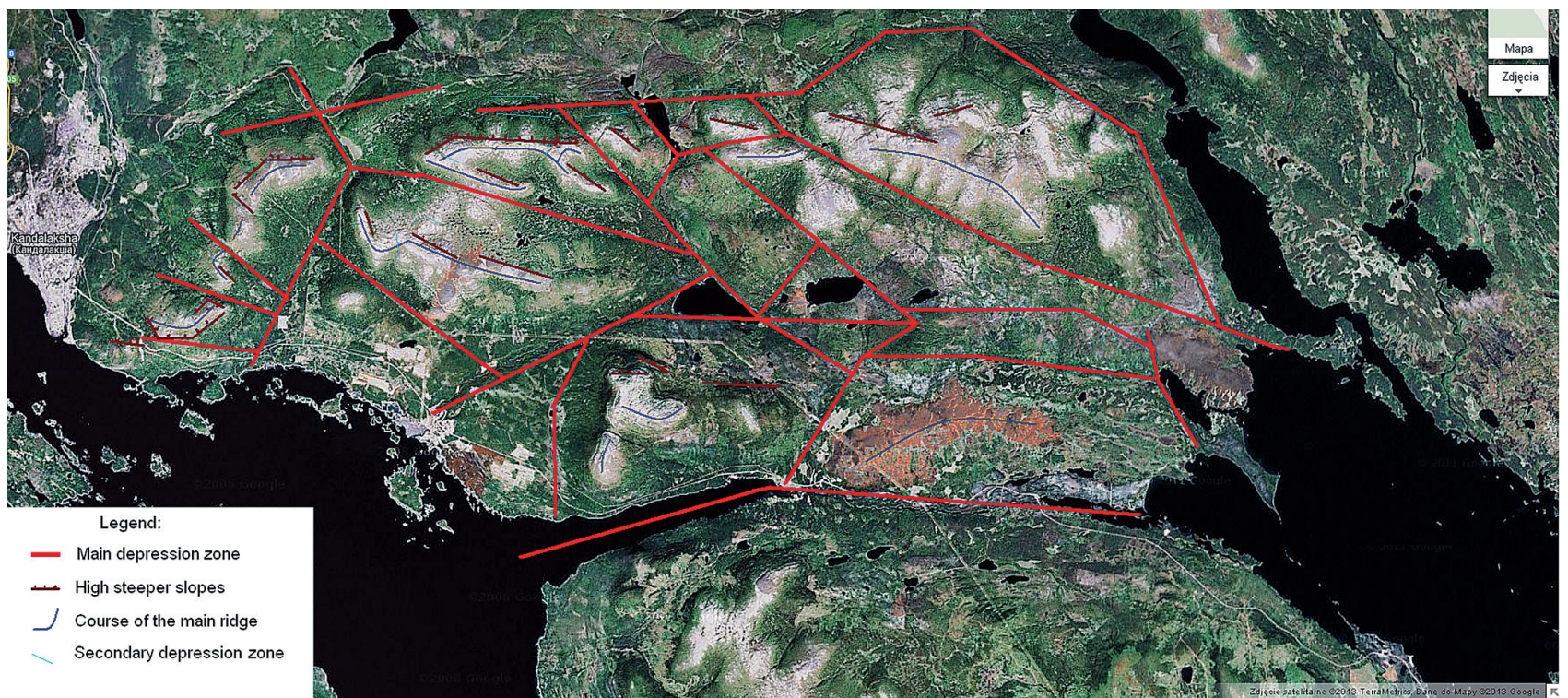

Fig. 8. Structural elements in the relief of the Kandalaksha region (photo based on Google Maps)

are of elongated rectangular shape and their long axis is WSW-NNE oriented $\left(22-25^{\circ} \mathrm{N}\right)$. Some of the mesoblocks descend stepwise towards the shoreline. The top surfaces of the blocks, up to approx. $50 \mathrm{~m}$ a.s.l., are eroded by marine abrasion.

The greatest diversity is shown by meso- and microblocks within the studied portion of macroblock B. These forms are in different shapes: rhomboid, triangle or trapezium (Fig. 3), depending on the direction of the separating faults. The microblocks, whose escarpments correspond to the directions of the joints, have a similar shape (Fig. 4). In most cases, the long axis of the blocks is SWNE oriented (approx. $45^{\circ} \mathrm{N}$ ), but in the vicinity of the tectonic zone that separates macroblocks A and B, the blocks are NW-SE oriented. Denuded monadnocks transformed by the ice sheet occur on nearly every surface of the blocks.

Their stepwise descent towards tectonic zone 3 is a distinguishing characteristic of mesoblocks in macroblock $\mathrm{C}$. The long axis of the convex forms is SW-NE and SSW-NNE oriented. Only in the vicinity of the Vielikiy Kolos lake, the mesoblocks are parallel to the main tectonic zones (3 and 4). Within macroblock D, on the other hand, the meso- and microblocks are in rectangular and rhomboidal shape. Most of the long axes are SE-NW and SW-SW-NE oriented.

Macro-, meso- and microblocks are delimited by slopes of tectonic origin, of varying length, relative height and orientation. Some of them are straight, with a steep inclination, which evidences their young age. Other blocks have been transformed by erosion processes to a varying degree.

Closed depressions, currently filled with lakes, occur at the intersection of tectonic zones and individual faults. The shape of these depressions corresponds to the direction of the dislocation, e.g. the Vielikiy Kolos lake (Fig. 6). Small depressions separating the microblocks are the most numerous. They are straight or broken, narrow, with steep slopes. Their directions coincide with the directions

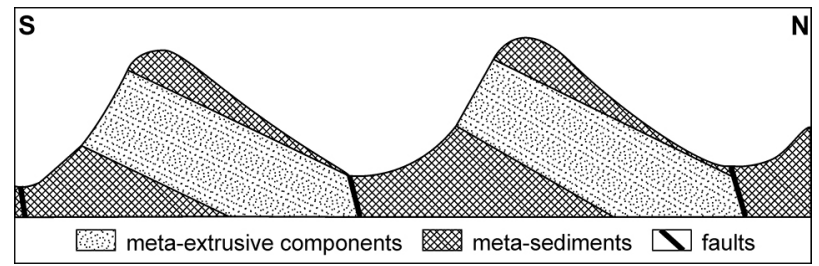

Fig. 9. Synthetic geological-morphological section across the hills in the Kandalaksha region

of the joints. Small tension fractures, several dozen centimetres wide, occur within macroblock A. The "freshness" of these forms indicates their contemporary origin.

The north-western part of the Lapland Granulite Belt has an entirely different structural relief than the Dalnye Zelentsy region (Fig. 8). A latitudinally oriented macroblock, composed of metamorphic rocks, occurs east of Kandalaksha. Flattened hills, not very high (up to $700 \mathrm{~m}$ a.s.l.) and elongated along the W-E and NW-SE direction, predominate within the block. A few hills are N-S oriented. Beneath the culminations, broad planation surfaces are visible, along with numerous boulders and post-glacial lakes. The hills have an asymmetrical cross-section: one slope is steep, the other is gentle (Fig. 9). This is linked with the erosion resistance of the rocks: the steep slopes feature outcrops of hard metamorphic lava rocks (amphibolites), while the gentler slopes feature less hard metamorphic sedimentary rocks (amphibolite/quartz shales). Hence, the steep slopes are cuestas. Numerous hollows caused by corrasion occur on the slopes; their location is linked with the orientation of tectonic fractures - mainly in the following directions: $71 / 85,344 / 30$, 101/65, 61/72, 181/50 (Fig. 5). The hills are dissected by numerous valleys, with visible effects of glacial activity (U-shaped cross-section and numerous concentrations of boulders). In the fault zones (WSW-ENE and NW-SE oriented), concave forms occur, namely river valleys and depressions. These forms run parallel to the orientation of the hills mentioned above. 


\section{Periods and determinants of the development of the structural relief of the Kola Peninsula}

The structural relief of the Murmansk Terrane mainly corresponds to the faults and joints. The formation of disjunctive forms is linked with post-Devonian and post-glacial tectonic movements (Apukhtin 1958). The latter movements are ascribed a significant role in the reactivation and development of secondary dislocations having the character of normal faults (Bussien 1964). The Pleistocene age of tectonic movements was also accepted by Kozlow (1972). Grabens, breaks and tectonic fissures and horsts of different orders thus formed as a result of periodic, glacio-isostatic uplift of the Murmansk Terrane after each Scandinavian glaciation. The last, post-glacial tectonic movements, to the order of approx. $40 \mathrm{~m}$, resulted in the formation of numerous open fissures in the study area (Mitiaev, Gierasimova 1994). Normal faults of glacio-isostatic origin were also found in another part of the Baltic Shield (Lundqvist, Lagerbäck 1976). The age of the particular structural forms cannot be determined with certainty. One can only differentiate between forms older and younger than the last deglaciation of the ice sheet. The old concave forms contain glacial sediment layers, while the young forms are fresh, free of glacial sediments.

The structural relief of the Murmansk Terrane is determined by disjunctive structures. Large and long depressions are mainly tectonic semi-grabens of step-like structure; the smaller ones formed as a result of erosion of fractured rocks in the fault zones, whereas small and straight depressions, separating microblocks of the same absolute heights, probably formed on joints. This proposition is confirmed by the fact that the directions of the depressions coincide with the directions of joints (longitudinal and transverse). The surface of the tectonic blocks generally descends towards the Barents Sea, which may indicate that the entire Murmansk Terrane is inclined to the north-east.

Hills in the Kandalaksha region formed on hard, layers of meta-volcanic and meta-intrusive rocks inclined to the north, while the depressions are linked with mylonitisation zones and occurrence of meta-sedimentary rocks (Bridguoter et al. 1999). Disjunctive structures determine the concave forms on meso-scale (valleys, passes), but the slopes do not have a step-like character. These forms probably developed over an extended period of time. The last period of their formation was the Pleistocene when the ice sheet was the main relief-forming factor. In places where the rocks are highly fractured, frost weathering is now active, causing the recession of slopes.

\section{Conclusions}

The structural relief of the two areas compared varies, similarly to their geological structure. In the Dalnye Zelentsy region, depressions and tectonic blocks of varying size and order predominate, while to the east of Kan- dalaksha - flattened hills with asymmetrically inclined slopes (of cuesta character) with visible corrasion troughs and U-shaped valleys separating the individual hills. In the Dalnye Zelentsy region, the relief was developed on igneous rocks (granitoids), while in the Kandalaksha region, on metamorphic rocks (amphibolites, granulites and eclogites).

Within the Murmansk terrane, the hardness of the rocks does not have a huge significance for the type of relief since the rocks are rather uniform lithologically. Disjunctive structures - i.e. the tectonic zones, faults and joints - constitute the main structural factor determining the development of relief. In the Kandalaksha region, the opposite is the case. The relief of the analysed macroblock is closely linked with the formation and position of the rocks. It can be described as escarpment relief.

The final stage of the development of structural relief is linked with Pleistocene glaciations. The advances and recessions of the ice sheets were the reason for the glacial isostatic adjustments that resulted in the rejuvenation of tectonic zones and fracturing of rocks. Also in the Pleistocene, the structural relief was transformed in some places by marine processes (abrasion), glacial processes (exaration) and frost processes (physical weathering).

\section{References}

Apukhtin N.I., 1958. Gieomorfologia. Gieologia SSSR. T. XXVII. Murmanskaya oblast. Gosudarstwiennyje nauchno-tekhniczeskoye izdatielstwo litieratury po gieologii i okhranie niedr. Izd. „Nauka”, Moskwa.

Armand A.D., Grave L.M., Kudlaieva A.L., 1969. Povierkhnosti vyravnivania i kory vyvietrivania Murmanskoi oblasti. In: Osnovnyie problemy geomorphologi i stratigraphy antrpogena Kolskogo Polustrova. Nauka, Leningrad: 112-123.

Balagansky V.V., Mudruk S.V., Gorbunov I.A., Raevsky A.B., 2012. Tectonics of detached middle crust in the north-eastern foreland of the Palaeoproterozoic Lapland-Kola collisional orogen, north-eastern Baltic Shield. Proceedings of the MSTU 15: 300-310.

Bogatsky V.I., Bogdanov N.A., Kostyuchenko S.L., Senin B.V., Sobolev S.F., Shipilov E.V., Khain V.E., 1996. Explanatory notes for the tectonic map of the Barents Sea and the northern part of European Russia, scale 1:2,500,000. Moscow.

Bogdanova M.N., Efimov M.M., Kaulina T.W., 1996. Geochronologia kluchevych etapov rannieproterozoiskogo magmatisma w kolizionnoi zonie bialomorskogo-laplandskogo pasa baltyiskogo shchita (kolvickaya zona). Doklady Russkyi Akademii Nauk, Geokhimia 350(5): 665-668.

Bogdanova M.N., Efimov M.M., Sorochtin H.O., Balaszow J.A., Hannibal L.F., Rungienen G.I., 1993. Rozvitie polimetamorfisma w granulitowom pojasie kolskogo poluostrova (kolvickaya zona) i U-Pb datirovka anortozytovoi diaftorezy. Doklady Russkoi Akademii Nauk, Geologia 331(3): 332-331,

Bridguoter D., Scott D., Balagancky W.W., Timmerman M.J., Marker M., Bushmin S.A., Aleksieyev H., Daly J.S., 1999. Priroda rannyiedokiembryiskich metaosdakov w laplandsko-kolskom poiasie po $207 \mathrm{~Pb} / 206 \mathrm{~Pb}$ resultatach datirovki ziern zirkonov i Sm-Nd izotopowych dannych celych porod. Doklady Ruskoi Akademii Nauk, Geologia HM 366(6): 664-668.

Bussien I.W., 1964. Proiavlenie poslelednikowykh dislokacyi v reliefie yuznovo skwona Luyavryta (centralnaya chast Kolskogo Poustrova). In: Relief i geologicheskoye stroyenie osadochnovo pokrova Kolskogo Polustrova. Nauka, Moskva-Leningrad: 77-79. 
Gaal G., Berthelsen A., Gorbatschev R., Kesola R., Lehtonen M.I., Marker M., Raase P., 1989. Structure and composition of the precambrian crust along the POLAR Profile in the northern Baltic Shield. Tectonophysics 162: 1-25. http://dx.doi.org/10.1016/0040-1951(89)90354-5

Goliszek M., Pękala K., 1996. Development of contemporaneous slope processes in the Dalnie Zelentsy region (Kola Penisula). In: Wyprawy Geograficzne na Spitsbergen. UMCS, Lublin: 147-152.

Grave M.K., Kozlova A.E., Timophieyev D.A., 1991. Tipy relief Kolskogo Polustrova: opyt terminologicheskovo analiza. Geomorfologija 3: 65-71.

Grave M.L., 1966. O proiavlieni razryvnykh dislokacyi v reliefie centralnoy chasti Murmanskogo bloka (po matieriawom aerophotosyomki). In: Formirovanie relief I chetviertichnykh otwozeniy Kolskogo Polustrova. Nauka, Moskva: 90-100.

Harasimiuk M., Superson J., Zgłobicki W., 1996. Polygenesis of the relief of the northern part of Murmansk Plateau exemplified by the Dalnie zelentsy region. In: Wyprawy Geograficzne na Spitsbergen. UMCS, Lublin: 153-161.

Hättestrand C., Clark C.D., 2006. The glacial geomorphology of Kola Peninsula and adjacent areas in the Murmansk Region, Russia. Journal of Maps: $30-42$.

Korja T., Tuisku P., Pernu T., Karhu J., 1996. Field phetrophisycal and carbon isotope studies on the LGB implications for deep continental crust. Terra Nova 8: 48-58. http://dx.doi.org/10.1111/j.1365-3121.1996.tb00724.x

Kozlov M.T., 1972. Niekotoryie cherty gubinnovo stroyenia Kolskogo Polustrova i kharacter sovremiennykh dvizeniy. In: Issledovanie stroyenia i sovremiennykh dvizeniy ziemnoy kory na kolskom, geophizicheskom poligonie. Nauka, Moskva: 40-48.

Kozlov N.E., Ivanov A.A., Nyerovich L.I., 1990. Lapland, Granulite Belt, Primary origin and development. RAN, Apatity, Russia.

Kozlova N.E., Riezhenova S.A., 1998. Geneza eklogitopodobnych skał Laplandzkiego Pasa Granulitowego HM. Dokłady Rosyjskiej Akademii Nauk, Geologia 361(3): 78-380.
Kozlow N.E., Ivanov A.A., 1991. Composition of metamorphic rocks and some aspects of evolution of the Lapland Granulite Belt on The Kola Peninsula, USSR. Geological Survey of Norway, Norges Geologiske Undersøklese 421, Trondheim, Norway: 19-32.

Lundquist J., Lagerbäck R., 1976. The Parve Fault: A late glacial fault in the Precambrian of Swedish Lapland. Geol. For. Forh. 98(1).

Mitiaev M.V., Gierasimowa M.V., 1994. Morphological structure and neotectonics of the coastal zone of the Murmansk east sea-shore (Watershed zone of the Voronia and Rynda Rivers). In: Wyprawy Geograficzne na Spitsbergen. UMCS, Lublin: 79-85.

Mitrofanov F.P., 1999. Dokyembryiska tektonika severo-wostochnoi czasti Baltyiskogo Shchita. Nauka, St. Petersburg.

Mitrofanov F.P. (ed.), 2001. Geologicheskaia Karta Kolskogo Regiona. Apatity.

Mitrofanov F.P., Balagancky V.V., Balashov Y.A., Gannibal F.G., Dokuchaeva V.S, Nerovich L.I., Radchenko K., Ryungen G.I., 2000, $\mathrm{U}-\mathrm{Pb}$ age of gabro-anortosite massifs the LPG. Norges Geologiske Undersøkese: 179-183.

Pękala K., 1994. Development of relief affected by contemporary morphogenetic processes in the Dalnye Zelentsy region (Kola Peninsula). In: Wyprawy Geograficzne na Spitsbergen. UMCS, Lublin: 87-92.

Superson J., 1994. Main elements of relief and Quaternary sediments in Dalnye Zelentsy region (Kola Peninsula). In: Wyprawy Geograficzne na Spitsbergen. UMCS, Lublin: 107-111.

Terekhov E.N., Baluev A.S., Przhijalgovskii E.S., 2010. Structural position of Devonian alkaline occurrences in the Kola Penisula. In: Abstracts of XXVII International Conference School "Geochemistry of Alkaline rocks". Moscow-Koktebel.

Tuisku P., Huhma H., 1998. Eclogite from SW - Marginal zone of the LGB: evidence from the 1,9-1,8 GA Subduction Zone. International Ophiolite Symposium and Field Excursion, Espoo, Finland.

Zgłobicki W., 1994. Tectonics of the Dalnye Zelentsy region. In: Wyprawy Geograficzne na Spitsbergen. UMCS, Lublin: 127-132. 